\title{
From Symbiosis to Separate Spheres? England, 1163
}

\author{
Judith A. Green*
}

This paper focuses on discussions of Christian kingship in 1163, a critical year in the relationship between King Henry II of England and Thomas Becket, archbishop of Canterbury. On the basis of the revised Lives of Anselm (by John of Salisbury) and Edward the Confessor (by Aelred of Rievaulx), it is clear that traditional views of a symbiotic relationship were still very much to the fore, even though the quarrel between king and archbishop was to lead ultimately to a clearer separation of secular and ecclesiastical jurisdictions.

Keywords: John of Salisbury; Thomas Becket; Henry II; Pope Alexander III; Council of Tours; Council of Westminster

In the idealized picture drawn by the English monk Eadmer (d. c. 1126) of relations between Archbishop Dunstan of Canterbury (d. 988) and King Edgar (d. 975) in the tenth century, Dunstan was the king's pre-eminent counsellor, guiding Christian society. ${ }^{1}$ This was the starting point of Eadmer's Historia novorum, written around 1110, as the background - as he thought - to the quarrel between a later Canterbury archbishop (and Eadmer's friend), Anselm, and the Norman kings of post-Conquest England. The ideas of schurch and state or schurch and society « would of course have been incomprehensible in the later tenth century. By the late twelfth century, however, as outlined by Christopher Cheney in From Becket to Langton, only individual archbishops and bishops were influential as royal counsellors or justices: there was now a line - admittedly fuzzy in places - between ecclesiastical and secular jurisdictions, and the pope's authority over the English church was much more immediate than it had been two centuries earlier. ${ }^{2}$

Understanding why and how dividing lines were coming to be drawn has been one of my recent preoccupations in tracing the history of power in English society between the late tenth and twelfth centuries. My interest lies not only in the changing ways power was exercised, but also in areas of friction and occasional conflict, as well as the compromises that were made between those with power - kings, lay lords, and churchmen. The origins of this paper lie then in a larger argument about the nature of English political society. ${ }^{3}$ Here the focus is on the year 1163, on the trouble brewing between King Henry II (d. 1189) and Archbishop Thomas Becket of Canterbury (d. 1170), and on one basic point: that even if in

* Correspondence details: Judith Green, School of History, Classics and Archaeology, University of Edinburgh, William Robertson Wing, Teviot Place, Edinburgh EH8 9AG. Email: Judith.Green@ed.ac.uk.

1 Eadmer, Historia Novorum, ed. Rule, 3.

2 Cheney, From Becket to Langton. See also Duggan, Clerical Exemption, in this special issue.

3 For a broader exposition, see Green, Forging the Kingdom. 
the long term one might argue that the quarrel was to lead to a sharper distinction between secular and ecclesiastical jurisdictions and to a stage in the rise of a secular state in England and perhaps more widely in Europe, nonetheless, ideas that were circulated in that year about the king's role in Christian society still reflected notions of symbiosis rather than separate spheres.

The following discussion centres on two authors, John of Salisbury, who wrote the Life of Anselm, and Aelred of Rievaulx, author of the Life of King Edward. Both books were revisions of earlier texts, the former of Eadmer's Life and the latter of the life of King Edward by Osbert of Clare. ${ }^{4}$ The visions they presented were composed for particular ends, but they show what some believed were models of the behaviour of archbishops and kings. ${ }^{5}$

\section{Becket and the Life of Anselm}

The factors for change in the relationship between the kings of England and their archbishops between the late tenth and late twelfth centuries may be arranged under three headings. First was the eleventh-century reform movement which aimed to establish the priesthood as a separate and celibate order, free from worldly entanglements. Much attention had been given to the problem of lay investiture, leading to difficulties between Archbishop Anselm and King Henry I in the early twelfth century. Second, there was the growing influence of the papacy over the western church, and the concomitant rise of studies of church law with the search for clarification and precision. Third, there was the accession in England of King Henry II in 1154, following a period of contested rule. Henry, young and vigorous, was concerned to restore order, both in terms of suppressing violence and resolving disputes over land. He was also determined to recover lost lands and certain rights of the crown, especially those which were lucrative, and this was by no means an easy task. ${ }^{6}$ As part and parcel of these efforts he sought to rein in the excesses of officials, both his own, the sheriffs, and those of others, the archdeacons, baronial stewards and reeves.

This was the context in which Thomas Becket became the new Archbishop of Canterbury, the most powerful cleric in the English church. Becket must have seemed the ideal successor to Archbishop Theobald of Canterbury, who died in 1161 when the king was out of England. As chancellor, Becket was at the heart of the royal administration and knew well its challenges and constraints. He had been involved first hand in the administration of royal justice, and as archdeacon of Canterbury he had experience and knowledge of the archbishop's problems with the king, and potential jurisdictional conflicts. When he became archbishop of the most powerful see in England, he proved anything but a pliable tool. As archbishop, his initial concerns were: 1) to restore lost lands and rights to Canterbury; 2) to reassert the Canterbury primacy, not just over York but over the whole of the British Isles; 3) to see Archbishop Anselm's claim to sanctity recognised; and 4) to secure the grant of a papal legation.

Of these four, only the Canterbury primacy presented no problems to King Henry II, as it had long suited the Norman kings to back Canterbury. ${ }^{7}$ Indeed, the ramifications of the Canterbury primacy over Wales, Scotland and Ireland, strengthened Henry's claim to overkingship and, more immediately, laid the ground for an invasion of Ireland, mooted as early 
as $1155 .{ }^{8}$ Henry would not have appreciated the efforts being made by bishops of St Davids and St Andrews to achieve archiepiscopal status for their sees, as this in effect buttressed claims to national churches and thus to independent nationhood. We may assume that the king had no objections when Archbishop Thomas went to the Council of Tours called by Pope Alexander III (d. 1181) in May 1163 hoping for a recognition of his primacy. Archbishop Roger of York, his senior in terms of date of consecration, argued however that he should take precedence, and in the end the archbishops were awarded parity. Thomas was accorded much respect but not papal recognition of Canterbury's primacy. ${ }^{9}$

Thomas had also however gone to Tours hoping for papal recognition of Anselm's sanctity, for this was an era when popes were taking charge of the process of canonization. Becket's advocacy of Anselm sprang from a mixture of motives. His veneration was sincere: he carried a copy of Anselm's Prayers and Meditations which he used in daily worship. ${ }^{10} \mathrm{He}$ also however needed to establish his position at Canterbury. He was well aware that there had been opposition to his appointment amongst the monks as well as the episcopate, and there may have been reservations at Rome. ${ }^{11}$ Anselm was not only a saintly figure and noted intellectual worthy of canonization, but the themes of Eadmer's Life, Anselm's reluctance to take up office, and his preparedness to suffer exile, perhaps struck a chord with the new archbishop. ${ }^{12}$

The task of repackaging Eadmer's Life of Anselm to obtain formal papal acknowledgement of the saint was delegated to John of Salisbury, then a member of the archbishop's household, with experience of the papal curia, and a noted Latinist. ${ }^{13}$ Only one manuscript of John's Life is known to survive, in Lambeth Palace, MS 159, a collection of texts relating to Christ Church Canterbury made in 1507 by a Canterbury monk. John's work evidently attracted little attention, by comparison with his Life of Becket, and indeed his other works. ${ }^{14}$ His Life of Anselm drew heavily on that by written a generation earlier by Eadmer. ${ }^{15}$ However, it is more than a simple abridgement. John described Anselm as Beatus, or uir apostolicus. ${ }^{16}$ He retold the episodes which show Anselm's ability to heal the sick and to come unscathed through fire and tempest, likening him at several points to other saints, including St Martin of Tours. ${ }^{17}$ He added one miracle, the healing of a disabled man named Elphege at St Anselm's tomb, and he noted Anselm's disdain for worldly wealth. ${ }^{18}$ This was a hagiographic brief focussed on Anselm's personal holiness and his scholarly distinction, so John did not have to go into

Robert of Torigny, Chronicles of the Reigns of Stephen, Henry II and Richard I, ed. Howlett, 4, 186.

Somerville, Pope Alexander III; Materials for the History of Thomas Becket, ed. Robertson, 3, $250-255$.

o Materials for the History of Thomas Becket, ed. Robertson, 3, 210-211.

Christensen, Curious Case of Becket's Pallium, 243-256.

2 Staunton, Eadmer's Vita Anselmi, 1-14.

13 For recent work on John see Grellard and Lachaud (eds.), Companion to John of Salisbury.

14 The most readily available edition cited here is John of Salisbury, Vita Anselmi, ed. Migne, cols. 1009a-1040c. At both the beginning and end of the Life John's authorship is made clear, London, Lambeth Palace MS 159 ff. $160 v$, 176r. For an English translation, see Anselm and Becket, ed. Pepin. A verse epitome made later in the twelfth century survives: Sheerin, Anonymous Verse Epitome.

15 Gameson, Earliest Books of Canterbury Cathedral, 242.

16 John of Salisbury, Vita Anselmi, ed. Migne, cols. 1009B, 1014A.

17 John of Salisbury, Vita Anselmi, ed. Migne, cols. 1012C, 1037B.

18 John of Salisbury, Vita Anselmi, ed. Migne, col. 1040A. 
detail about his subject's travails with the Norman kings. He abbreviates Eadmer's account of Anselm's reluctance to take up the office of archbishop and his quiet determination to leave the country to go to Rome. He is very brief indeed on Anselm's refusal to accept bishops who had performed homage to Henry I, saying the events "would take too long to narrate «. ${ }^{19}$

Where we see John's handiwork in particular is on two issues, the Canterbury primacy and royal tyranny. John reported that Pope Pascal II (d. 1118) had confirmed Canterbury's primacy of Britain and gave Anselm the privilege of being exempt from the commands of all papal legates. ${ }^{20} \mathrm{He}$ further included Anselm's letter to Thomas, archbishop-elect of York, threatening to anathematize him if he did not make his profession to Canterbury. John related the story (not in Eadmer) of Anselm's remark that he would not dare appear before God until he had punished the archbishop of York. ${ }^{21}$ Secondly, John's denunciation of William Rufus as a tyrant was not in Eadmer. ${ }^{22}$ So we have a picture of a saintly, outspoken archbishop, whom Henry I urged to return from exile in 1100 despite his frank criticism of the king's predecessor, and on whose counsel all the affairs of the kingdom waited. Subsequently in England, king and archbishop convened a council at which the king promised not to practise investiture in the future.

In any event, the presentation of Anselm's revised life to the pope at Tours proved to be in vain. On the grounds that there were too many dossiers presented for discussion (including that of St Bernard), the pope referred the case back to England, and to a provincial council, which Becket of course never had the time or royal backing to call. ${ }^{23}$ It may be that the pope was partly motivated by a reluctance to annoy Henry II, for Anselm was of course a symbol of resistance to Norman kings: to William Rufus who had refused to allow him go to Rome, and to Henry I on the questions of investiture and homage. As a loyal servant of Rome prepared to suffer exile for his beliefs, Anselm was not someone of whom Henry II wished to be reminded, not least by John of Salisbury. John had already experienced the king's displeasure on a previous occasion. ${ }^{24}$ Yet John's - and we might surmise, Thomas's - Anselm was not in outright opposition to his kings: that there were problems was not glossed over, but as John emphasised, friendship and co-operation between the two was restored at Bec.

19 John of Salisbury, Vita Anselmi, ed. Migne, cols. 1031c-1031d.

20 John of Salisbury, Vita Anselmi, ed. Migne, cols. 1032a-1032b.

21 John of Salisbury, Vita Anselmi, ed. Migne, cols. 1034d-1035b; cf. Eadmer, Historia novorum, ed. Rule, 206.

22 John of Salisbury, Vita Anselmi, ed. Migne, col. 1030a; cf. col. 1021c: parum justus aut pius: prodigus sui, appetens alieni, ferarum amantissimus, sed negligentissimus animarum, fautor militiae et malitiae, sed Ecclesiae et innocentiae vehementissimus oppugnator, voluptatis sectator acerimus: utpote in quo sine modo et mensura vigebant pariter amor mundi et contemptus Dei. See also the comment qui vixerat bestialiter, bestialem invenerat exitum vitae, col. 1030c.

23 Thomas Becket, Correspondence, ed. Duggan, I, no. 10. There are signs that the feast of Anselm's translation was put in hand at Canterbury, for a Christ Church Calendar pre-dating Becket's murder includes the translation on 7 April and the feast on 21 April: Southern, St Anselm and his Biographer, 339-340.

24 The Letters of John of Salisbury I, ed. Millor and Brooke, Appendix II, The Great Disgrace, 257-258. It seems that the cause of John's sdisgrace r was related to a stay at Rome, and the terms on which Pope Adrian IV made a grant of Ireland to Henry II; Duggan, John of Salisbury and Thomas Becket, 429-430. 


\section{Becket and the relics of King Edward}

When the archbishop returned from Tours in the summer of 1163, he had failed to achieve a recognition of the Canterbury primacy, the canonization of Anselm, or the status of papal legate. ${ }^{25} \mathrm{He}$ faced a king who had come back to England in January of that year after an absence of more than four years, determined to reassert his authority, renew a drive to restore order and to punish wrongdoing, to rein in venal officials (his own and other people's), and to make sure he was getting his revenues in full. His fundamental approach remained that of turning back the clock to his grandfather's day, whether this was to do with the scope of royal justice or relations with Rome. In Normandy his justices had been active, as they were in England in $1163 .{ }^{26} \mathrm{He}$ had also renewed the canons of the Council of Lillebonne of 1080. These had much to say about the scope of episcopal and archidiaconal jurisdiction, and had been confirmed by Henry I. ${ }^{27}$

On the king's return there was a mass of lawsuits to be dealt with, some of which involved the archbishop. As well, several sheriffs were dismissed. ${ }^{28}$ The king also had dynastic affairs to consider. In 1162 his heir, also named Henry, had returned to England with his guardian, the archbishop, and the plan was for the great men to pay homage to the heir. ${ }^{29}$ At the Council of Woodstock in July 1163, the Welsh and Scottish princes paid homage, not just to the king but also to his son. Henry also floated a plan to levy an aid on land at the old danegeld rate of two shillings a hide, taking over an aid customarily paid to sheriffs. ${ }^{30}$ Becket opposed him, on the grounds that those liable would not only have to pay this levy but also an aid to the sheriffs, and the plan was dropped. Underlying the king's plan was an effort to take an annual land tax without the widespread exemptions achieved by religious communities that had been founded in 1135 or later. The liability of the archbishop's land to geld, to military service, and to aid, was very substantial. Whether Becket's stance was personal or representative of wider opposition is unclear, but it aroused the king's anger at a time when black marks against the archbishop were adding up.

A council of lay and ecclesiastical magnates assembled at Westminster at the start of October 1163, and there were various items on the king's agenda. He was annoyed by the way archdeacons were bringing charges in church courts on a wide range of issues, including cases of moral backsliding, such as the burgess of Scarborough who had been charged with adultery ${ }^{31} \mathrm{He}$ was particularly angered about the leniency showed to clerks accused of

25 Thomas Becket, Correspondence, ed. Duggan, I, no. 71.

26 White, Restoration and Reform, 180-212.

27 Robert of Torigny, Chronicles of the Reigns of Stephen, Henry II and Richard I, ed. Howlett, 4, 212; for the canons, Orderic Vitalis, Ecclesiastical History, ed. Chibnall, 3, 26-34.

28 There were several flashpoints here. One was over Tonbridge, held by Earl Roger de Clare who refused homage for the castle, though this was technically situated on Canterbury land. Another was over Saltwood, confiscated by the king from the disgraced Henry of Essex, even though the castle and attached lands were held of the archbishop and not of the king. A third was over the archbishop's excommunication, without asking the king's permission, of William of Eynsford, a tenant-in-chief, in a dispute over presentation to a benefice. In general see Duggan, Thomas Becket, ch. 2. For the sheriffs, see Boorman, Sheriffs of Henry II.

29 Robert of Torigny, Chronicles of the Reigns of Stephen, Henry II and Richard I, ed. Howlett, 4, 216.

30 Roger of Pontigny, Materials for the History of Thomas Becket, ed. Robertson, 4, 22-25.

31 William FitzStephen, Materials for the History of Thomas Becket, ed. Robertson, 3, 44. 
serious crimes, and requested that those who were convicted in the church courts should lose the protection of their clerical status and be handed over to the king's officers to prevent escape..$^{32}$ Becket and his fellow bishops refused to accede. The king asked instead that each should promise to obey his customs, but Becket gave only qualified assent ssaving his order<.

Becket's biographers tended to finish their account of the Council at this point: in this heated mood [Henry] left London without notice, with all his business unfinished, and lawsuits left hanging.$^{33}$ Of Becket's contemporary biographers, only William FitzStephen mentions the great ceremony which followed on 13 October, when King Edward's relics were translated..$^{34}$ The king and some of the greatest nobles carried the coffin through the cloisters in Westminster Abbey, in the presence of the archbishop, all but one of his suffragan bishops, and three Norman bishops..$^{35}$ Laurence, the abbot of Westminster, had asked his kinsman Aelred abbot of Rievaulx to compose a sermon for the event..$^{36}$ According to the sermon, which Aelred may have delivered in person, sexual purity and the gift of prophecy helped to establish Edward's saintly credentials. Edward had shaken off the yoke of captivity imposed by the Danes, he had bestowed wealth on the church, and he had a high reputation with the Franks and the Germans, who sought his friendship. Above all sthis Moses of ours ' was a lawgiver, who brought peace and justice to his realms.

Abbot Aelred's views about Christian kingship, his relations with Henry II, and his involvement in the cult of King Edward, were well established by the time the translation ceremony took place in 1163. He had already outlined his ideas in a Lament for King David of the Scots written a decade earlier. ${ }^{37}$ This lament prefaced a genealogy of the kings of the English, composed in 1153 shortly before Henry II's accession to the English throne, tracing his ancestry back through the maternal line to Adam, the cornerstone between the English and the Normans, fulfilling the prophecy of Edward the Confessor of the green tree, uniting the two races. ${ }^{38}$,When<, Aelred addressed Henry, 'you see the integrity of your ancestors, the virtue that shone out and the holiness that radiated from them, you will realize how natural it is to you to abound in riches, to excel in virtues, to be renowned in victories and, more than all this, to glow with Christian religion and the prerogative of righteousness. ${ }^{39}$

32 Summa Causae Inter Regem et Thomam, Materials for the History of Thomas Becket, ed. Robertson, 4, 201-205.

33 Summa Causae Inter Regem et Thomam, Materials for the History of Thomas Becket, ed. Robertson, 4, 205.

34 William FitzStephen, Materials for the History of Thomas Becket, 3, 261. It is interesting to read from one source that the main purpose of the council was to reaffirm the primacy of Canterbury, Summa Causae Inter Regem et Thomam, Materials for the History of Thomas Becket, ed. Robertson 4, 201-205.

35 For a detailed description, see Richard of Cirencester, Speculum Historiale de Gestis Regum Angliae, ed. Mayor, 2, 326-327; for discussion see Barlow, Edward the Confessor, 325-327.

36 Peterborough annals, Chronicon Angliae Petroburgense, ed. Giles, 98 as cited by Jackson, In translatione Sancti Edwardi Confessoris, 46. Walter Daniel mentioned Aelred's Life of King Edward, composed the request of his kinsman, Abbot Laurence: Walter Daniel, Life of Ailred of Rievaulx, ed. Powicke, 41-42. Aelred was an experienced hagiographer and his Lament and Genealogy had been markedly favourable towards Henry II, so doubtless Abbot Laurence would have had few misgivings about giving Aelred the commission.

37 As yet there is no modern edition of the Lament, see Aelred of Rievaulx, Historical Works, ed. and trans. Freeland and Dutton, 35, 45-70. For the genealogy, see Historiae Anglicanae Scriptores X, ed. Twysden, 347-370.

38 For a translation of the Lament, Aelred of Rievaulx, Historical Works, ed. and trans. Freeland and Dutton, 43-70.

39 Aelred of Rievaulx, Historical Works, ed. and trans. Freeland and Dutton, 71. 
Soon after becoming abbot of Westminster in around 1158, Laurence had turned his attention to the project of securing papal authorisation for the canonization of King Edward, an earlier attempt by Osbert of Clare having failed. Having laid the groundwork carefully, Laurence succeeded in 1161. He asked his kinsman Aelred to compose a Life of Edward the Confessor, based on the earlier Life written by Osbert of Clare..$^{40}$ Aelred's text was addressed to King Henry, whose special renown was his descent from such a holy line of kings, and again referred to the prophecy of King Edward that he would form the union of the Normans and the English. ${ }^{41}$ The Life emphasized the king's holy way of life, his celibate marriage, ability to foresee the future, and the miracles he worked. The message was of the king's integral role in society, and of the author's hope for the renewal of prosperity after the disaster wrought by the Norman Conquest. Miracles were reported, five which had probably been in a version of Osbert of Clare's text, plus four more..$^{42}$ Aelred may actually have composed his Life during a visit to the abbey early in 1163, though it was not until October that the translation ceremony took place. ${ }^{43}$ It was to be Aelred's Life which was to prove most popular to later hagiographers, though evidently not with Henry II or his sons, none of whom seem to have had much affection for Westminster abbey or the Confessor's cult. ${ }^{44}$

\section{Conclusion}

In the two almost contemporary texts considered in this article, John of Salisbury's Life of Anselm and Aelred's Life of King Edward, there are depictions on the one hand of ultimately cooperative relations between a saintly archbishop and the Norman kings, and on the other of an ideal holy king. Contrary to what is often assumed, the accession of Henry II, and then the appointment of his close friend as archbishop, opened up a new, possibly more harmonious, era in relations between king and archbishop. There was no inevitable progression in the quarrel between Becket and Henry from the relatively trivial and secular issues, such as sheriffs' aid, to the climacteric councils at Woodstock, Clarendon, and Northampton: there was no linear process of deteriorating relations and rapidly escalating quarrels.

In fact, the sequence of events was anything but linear. The juxtaposition of the Council of Westminster and the translation of King Edward, not mentioned by Becket's biographers, did not fit into such a sequence. Likewise, the dedication of the abbey church at Reading in April 1164 after the Council at Clarendon, showed the archbishop, despite his difficulties with the

40 Life of Saint Edward, ed. and trans. Freeland, 125-127; for recent discussions of this text, see Becquette, Ælred of Rievaulx's Life of Saint Edward; Yohe, Elred's Recrafting of the Life of Edward the Confessor.

41 Historiae Anglicanae Scriptores X, ed. Twysden, 370-414; for a translation, see Aelred of Rievaulx, Historical Works, ed. and trans. Freeland and Dutton, 123-143.

42 Aelred added four stories from Edward's lifetime: Edward catching the thief who stole from his treasury; Harold and Tostig fighting as children; the miserable death of Earl Godwin, now the villain of the piece; and the ring which Edward gave to John the Baptist.

43 Aelred's presence at Westminster on 6 March 1163 was noted by Powicke: Walter Daniel, Life of Ailred of Rievaulx, ed. Powicke, xciii.

44 Life of King Edward, ed. Barlow, Appendix D for a brief history of the cult; Mason, Westminster Abbey, 213-214; Bozoky, Sanctity and Canonization. 
king, presiding over a ceremony of great moment for the past and future of Henry's dynasty..$^{45}$ The abbey after all was home to the tombs of King Henry I, Queen Adeliza, and William, son of Henry II and Eleanor, as well as to a prized relic, the hand of St James. ${ }^{46}$

In 1163, then, conventional ideas about the relationship between a king and his archbishop, and about the role of a Christian king, were still potent in the minds of contemporaries. However, Becket and Henry also saw themselves charged with protecting their predecessors' legacies. The means by which these legacies were to be defended, the context of international politics in which events were played out, as well as the methods employed, led to confrontation, death, and ultimately to an enduring clarification of jurisdictions.

45 Previté-Orton, Annales Radingenses Posteriores, 400; Robert of Torigny, Chronicles of the Reigns of Stephen, Henry II and Richard I, ed. Howlett, 4, 221.

46 For Henry at Reading in 1158 and April 1163, see Eyton, Court, Itinerary and Household of Henry II, 38, 61-62. For the relic see Leyser, Frederick Barbarossa. For the tomb of William, see Robert of Torigny, Chronicles of the Reigns of Stephen, Henry II and Richard I, ed. Howlett, 4, 189. 


\section{References}

\section{Primary sources}

Aelred of Rievaulx, The Historical Works, trans. Jane P. Freeland, ed. Marsha L. Dutton (Kalamazoo, 2005).

Chronicon Angliae Petroburgense, ed. John. A. Giles (London, 1845).

Eadmer, Historia novorum, ed. Martin Rule, Rolls Series (London, 1884).

Eadmer, The Life of St Anselm, ed. Sir Richard Southern (Oxford, 1962).

Historiae Anglicanae Scriptores X, ed. Roger Twysden (London, 1652).

John of Salisbury, Anselm and Becket. Two Canterbury Lives by John of Salisbury, trans.

Ronald E. Pepin (Toronto, 2009).

John of Salisbury, Vita Anselmi, PL 199, ed. Jacques-Paul Migne, cols. 1009a-1040c.

Materials for the History of Thomas Becket, ed. vols. 1-6 James C. Robertson, vol. 7 by James C. Robertson and Joseph Brigstocke Sheppard, Rolls Series (London, 1875-1885).

Osbert of Clare, La vie de S. Edouard le Confesseur par Osbert de Clare, ed. Marc Bloch, Analecta Bollandiana, 41 (1923) 5-131.

Orderic Vitalis, Ecclesiastical History, ed. and trans. Marjorie Chibnall, 6 vols. (Oxford, 19691980).

Richard of Cirencester, Speculum Historiale de Gestis Regum Angliae, ed. John E. B. Mayor, 2 vols. Rolls Series (London, 1869).

Robert of Torigny, Chronicles of the Reigns of Stephen, Henry II and Richard I, ed. Richard Howlett, Rolls Series, 4 vols. (London, 1884-1889) 4, 81-315.

The Letters of John of Salisbury, Vol. 1: The Early Letters, ed. W. J. Millor and Christopher Nugent Lawrence Brooke, (Edinburgh, 1955).

The Life of King Edward who rests at Westminster, ed. Frank Barlow (Oxford, 1992).

Thomas Becket, Correspondence, ed. Anne. Duggan, 2 vols. (Oxford, 2000).

Walter Daniel, The Life of Ailred of Rievaulx, ed. and trans. M. Powicke (Oxford, 1950).

\section{Secondary sources}

Amt, Emilie, The Accession of Henry II in England. Royal Government Restored 1149-1159 (Woodbridge, 1993).

Barlow, Frank, Edward the Confessor (London, 1970).

Bequette, John P., Ælred of Rievaulx's Life of Saint Edward, King and Confessor: A Saintly King and the Salvation of the English People, Cistercian Studies Quarterly, 43 (2008) 17-40.

Boorman, Julia, The Sheriffs of Henry II and the Significance of 1170, in: George Garnett and John Hudson (eds.), Law and Government in Medieval England and Normandy (Cambridge, 1994) 255-275.

Bozoky, Edina, The Sanctity and Canonisation of Edward the Confessor, in: Richard Mortimer (ed.), Edward the Confessor. The Man and the Legend (Woodbridge, 2009), 173-186.

Cheney, Christopher R., From Becket to Langton: English Church Government 1170-1213 (Manchester, 1956).

Christensen, Katherine, The Curious Case of Becket's Pallium: Guernes de Pont-SainteMaxence and the Court of Alexander III, in: Peter D. Clarke and Anne J. Duggan (eds.), Pope Alexander III (1159-81): The Art of Survival (Farnham, 2012) 243-256.

Duggan, Anne, John of Salisbury and Thomas Becket, in: Michael Wilks (ed.), The World of John of Salisbury, Studies in Church History Subsidia 3 (Oxford, 1984), 427-438. 
Duggan, Anne, Thomas Becket (London, 2004).

Eyton, Robert W., Court, Itinerary and Household of Henry II (Dorchester, 1878).

Flanagan, Marie Thèrese, Irish Society, Anglo-Norman Settlers, Angevin Kingship: Interactions in Ireland in the Late Twelfth Century (Oxford, 1989).

Gameson, Richard, The Earliest Books of Canterbury Cathedral. Manuscripts and Fragments to c. 1200 (Dorchester, 2008).

Green, Judith A., Forging the Kingdom: Power in English Society 973-1189 (Cambridge, 2017).

Grellard, Christophe and Lachaud, Frédérique, A Companion to John of Salisbury (Leiden, 2015).

Hayward, Paul, Saints and Cults, in: Julia Crick and Elisabeth Van Houts (eds.), A Social History of England 900-1200 (Cambridge, 2011) 309-320.

Jackson, Peter, In translatione Sancti Edwardi Confessoris. The Lost Sermon by Ælred of Rievaulx Found?, Cistercian Studies Quarterly 40 (2005) 45-64.

Leyser, Karl, Frederick Barbarossa, Henry II and the Hand of St James, English Historical Review 90 (1975) 481-506.

Mason, Emma, Westminster Abbey and the Monarchy between the Reigns of William I and John (1066-1216), Journal of Ecclesiastical History 41/2 (1990), 199-216.

Previté-Orton, Charles W., Annales Radingenses Posteriores, 1135-1264, English Historical Review, 37 (1922) 400-403.

Sheerin, Daniel J., An Anonymous Verse Epitome of the Life of Anselm, Analecta Bollandiana, 92 (1974) 109-124.

Somerville, Robert, Pope Alexander III and the Council of Tours (1163) (Berkeley, 1977).

Southern, Richard W., St Anselm and his Biographer (Cambridge, 1966).

Staunton, Michael, Eadmer's Vita Anselmi: A Reinterpretation, Journal of Medieval History, 23 (1997) 1-14.

White, Graeme J., Restoration and Reform, 1153-1165: Recovery from Civil War in England (Cambridge, 2000).

Yohe, Katherine, Ælred's Recrafting of the Life of Edward the Confessor, Cistercian Studies Quarterly 38 (2003) 177-189. 